\title{
Study on the radial clearance of the screw conveyor for transporting cement
}

\section{Tung Thanh Luu*}

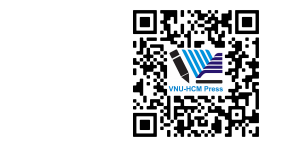

Use your smartphone to scan this QR code and download this article
Ho Chi Minh City University of Technology, VNUHCM

\section{Correspondence}

Tung Thanh Luu, Ho Chi Minh City University of Technology, VNUHCM

Email: ttluu@hcmut.edu.vn

History

- Received: 01-9-2019

- Accepted: 22-10-2019

- Published: 30-11-2019

DOI : 10.32508/stdjet.v2i3.577

\section{Check for updates}

\section{Copyright}

(c) VNU-HCM Press. This is an openaccess article distributed under the terms of the Creative Commons Attribution 4.0 International license.

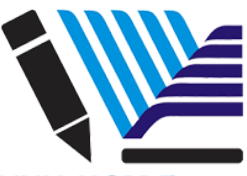

\begin{abstract}
Nowadays, screw conveyors have been used to transport bulk materials since historical times. They are composed of a helical flight (screw), a driving shaft connected to a driving device, a casing Utrough or pipe, and so on. The principle of conveying materials relies on the friction between materials and the rotating screw or the casing. The advantages of screw conveyors are compact design, low maintenance, and the ability to transport materials continuously and safely. Screw conveyors have been used not only as bulk handling equipment to transport materials but also as parts of construction and mining machinery, e.g., underground tunneling machines, in which they are used to discharge soil or rock continuously. As volumetric devices, screw conveyor generally provide relatively precise throughput control while meeting other requirements, e.g. environmental protection. A screw feeder typically consists of a storage container (bin or hopper) coupled to a screw casing and a screw within. They are suitable for conveying dry material or grain. Although mechanical structure of screw conveyor seems very simple, mechanic of transport action is very complicated. The periodic boundary, inclination, speed of rotation, radial clearance etc. influence productivity, mass flow rate. Following theoretical studies, the radial clearance should be very small, however, in reality, the bulk material cannot go through the clearance, that makes the screw stuck and then stop. However, when the radial clearance is larger, productivity decreases very fast. In this paper, the cement is transported by screw conveyor. The experiment is done with different parameters such as speed of rotation and the radial clearance. The productivity is recorded with each change of parameters. The result from the experiment will predict the best radial clearance to transport the cement. The paper will conclude the area having high productivity and low productivity.
\end{abstract}

Key words: Crew conveyor, speed of rotation, productivity, mass flow of rate, radial clearance

\section{INTRODUCTION}

The screw conveyors are very popular in transporting the bulk material such as industrial minerals, agriculture (grains), pharmaceuticals, chemicals, pigments, plastics, cement, sand, salt and food processing. They are also used for metering (measuring the flow rate) from storage bins and adding small controlled amounts of trace materials (dosing) such as pigments to granular materials or powders.

The structure of the screw conveyor is illustrated in Figure 1. The main components of the screw conveyor consist of:

- a hopper and a bin.

- Screw casing.

- Rotating screw.

The structure of rotating screw and screw casting affect the productivity much. The radial clearance between screw and casing plays an important role in ensuring productivity.
In A $\phi$ epo K. (1955) ${ }^{1}$, the clearance is very small about few millimeters. It must be small to prevent the hulk material to go through the gap. However, in reality, this clearance will make the material stuck when the rotational speed increases. The reason of the stuck problem is inertia of material. To decrease stuck problem, the radial clearance will increase. However, the larger clearance is, the more productivity reduces. The problem of clearance is to choose an optimal value of clearance.

In Alma Kurjak (2005) ${ }^{2}$, The clearance is a big influence on screw capacity. The reasonable clearance depends on size of particles. Particles larger than $250 \mu \mathrm{m}$ are usually relatively free flowing, but as size falls below $100 \mu \mathrm{m}$ powder become cohesive and flow problems are likely to occur. Powders having a particle size less than $10 \mu \mathrm{m}$ are usually extremely cohesive. The relation between size of particles and clearance is non-linear. This relation depends on cohesiveness of material, size. 


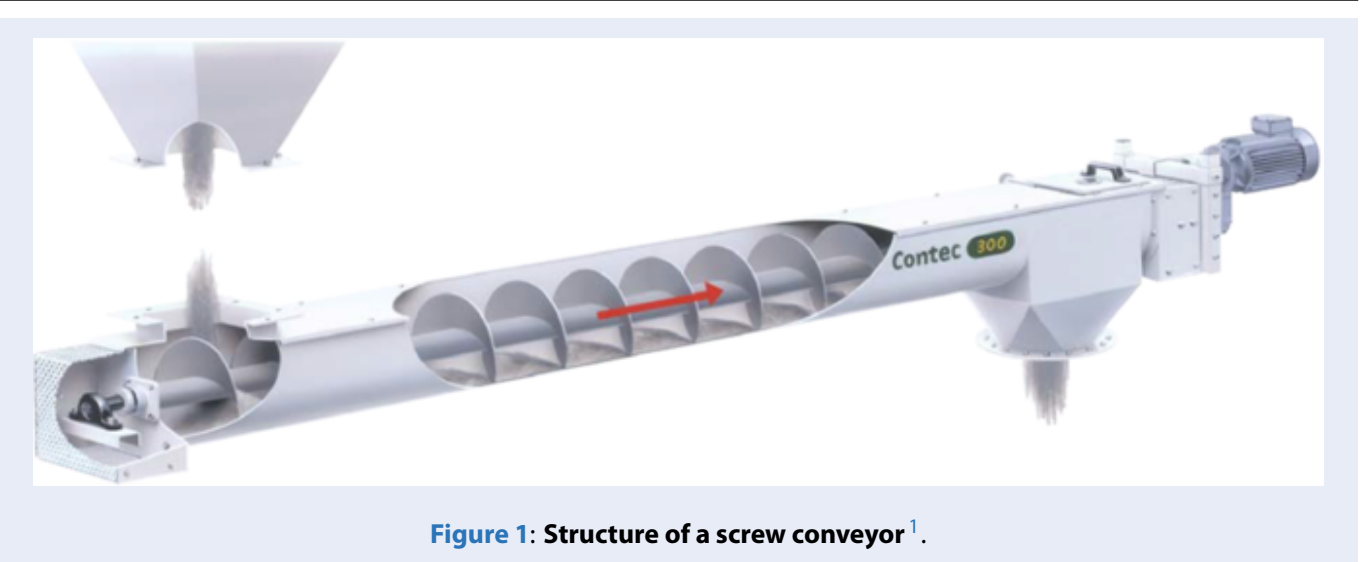

In Yoshiyuki Shimizul and Peter A. Cundall (2001) ${ }^{3}$ Yoshiyuki Shimizu1 and Peter A. Cundall show that clearance affect the net power. When clearance increase, the net power will more steady. However, the ratio between overall power and net one increase. The clearance depends on the friction coefficient between particles and screw components, and the material properties. To increase the productivity, the shaft will rotate with a threshold speed and then the particles reach equilibrium, the screw and the driving shaft are both rotated through three complete rotations at the specified, constant angular velocity, while the casing remains at rest.

A.W. Roberts in A.W. Roberts (1999) ${ }^{4}$ said the enclosed screw conveyor became more efficient at higher rotational speeds as a result of the reduced rotational speed or vortex motion of the bulk material. This advantage is usually more than offset by the decrease in 'fullness' of the conveyor that accompanies higher operating speeds. As the rotational speed of the conveyor increases, the rotational or vortex motion decreases up to a limiting value making for a more efficient conveying action. However, when a gravity feed system into the screw intake is employed, the feed rate cannot match the potential conveying capacity, and a reduction in 'fullness' occurs. The clearance will be chosen at least 1.5 times larger than the maximum particle size in order to prevent jamming of particles in the clearance space leading to particle attrition and increased energy loss. To prevent excessive slip back and loss of efficiency at higher angles of elevation, the clearance needs to be limited to a maximum value of about three times the maximum particle size.

To increase the power of handling, the speed of rotation is raised to 1000 round per minute. With that speed, the angle of incline and clearance will affect mass flow rate ${ }^{5,6}$. This affection is difficult to calculate. Thus, the experiment will be done to determine parameters to achieve the optimal mass flow rate. In this paper, the screw conveyor is used to handle the cement. Some parameters are designed with referring to A $\phi$ epo K. (1955) ${ }^{1}$, the radial clearance is calculated and experimented to find an optimal value to obtain the largest productivity. The next part is divided into 4 parts consisting of the theory of power, method, result and discussion. The conclusion will summarize the application in reality.

\section{MODEL DESCRIPTION}

In the screw conveyor, the productivity is a very important parameter ${ }^{1}$. It can be easily illustrated in Equation (1).

$$
\begin{gathered}
Q=Q_{t} \eta_{V} \quad\left(\mathrm{~m}^{3} / \mathrm{s}\right) \\
\text { where } Q_{t}=\Gamma \omega D^{3} \\
\Gamma=\frac{1}{8}\left(\left(1+2 \frac{C}{D}\right)^{2}-\left(\frac{D_{c}}{D}\right)^{2}\right]\left(\frac{p}{D}-\frac{t_{s}}{D}\right]
\end{gathered}
$$

$Q_{t}$ maximum theoretical volumetric throughput with conveyor running $100 \%$ full and the bulk material moving axially without rotation.

$\eta_{V}$ : volumetric efficient

$D$ : crew diameter $(\mathrm{m})$

$D_{c}$ : core or shaft diameter $(\mathrm{m})$

$p$ : Pitch (m).

$\omega$ : angular velocity of screw $(\mathrm{r} / \mathrm{s})$.

$C$ : Radial clearance (m).

$t_{s}$ : Thickness of screw blade (m).

The productivity efficiency of a crew conveyor consists of two components as follows.

$$
\eta_{V}=\eta_{V R} \cdot \eta_{F}
$$


where $\eta_{V R}:$ fullness efficientcy $=\frac{h_{a v}}{p}$

$h_{a v}:$ average height of material on the screw surface.

With the productivity is given in Equation (1), the angular velocity of main shaft $N_{s}$ is

$$
N_{s}=\frac{\omega^{2} R_{o}}{g}=\frac{N^{2} D}{1789}
$$

where $R_{O}$ outer radius.

$g$ : gravitation acceleration.

$\mathrm{N}$ : Rotation speed (round/minute).

The Equation (7) shows the screw conveyor of large diameter will attain the high productivity with low rotational speed when comparing with the conveyor of small diameter

With the volumetric given in Equation (1), the mass throughput of a screw conveyor in $\mathrm{kg} / \mathrm{s}$ is showed as follows.

$$
Q_{m}=\rho Q=\rho Q_{t} \eta_{v}
$$

where $\rho$ : bulk density, $\mathrm{kg} / \mathrm{m}^{3}$.

The bulk material density will increase when material is compressed in conveyor and the density will approach a maximum limiting value ${ }^{2}$. The bulk density is a function of major consolidation pressure for a typical cement sample.

A particle in a vertical crew conveyor will have a velocity diagram as Figure 3. $V_{S}$ is the screw velocity when it rotates. $V_{R}$ is particle's relative velocity with respect to the screw surface. $V_{A}$ is the absolute velocity of the particle by the helix angle $\lambda$.

To be simple in calculation, the velocity diagram (Figure 3) will be unfolded in Figure 4. The velocity diagram in which the absolute velocity is separated into two components, the useful conveying velocity $V_{L}$ and the rotational component $V_{T}$. The helix angle $a$ of the screw flight is smaller at the outer of the flight to the shaft. Similarly, angle $l$ also vary in the radial direction from the outside to the shaft. The variation of $V_{T}$ with radius illustrates the vortex motion in the screw. The variation of $V_{T}$ with radius describes the vortex motion in the screw. It is expressed by

$$
V_{T} r^{n}=\text { constant }
$$

The value " $n$ " is the vortex index ${ }^{2}$. It often equal zero, as a result, velocity component $V_{T}$ is constant and does not vary with the radius.
Following Figure 5 when actual conveying velocity $V_{L}$ is expressed as a ratio of maximum theoretical conveying velocity $V_{L t}$ it will provide a measure of conveying efficiency allowing for losses resulting from the rotational or vortex motion. It will be expressed that

$$
\frac{V_{L}}{V_{L t}}=\frac{\tan \lambda}{\tan \alpha+\tan \lambda}
$$

In the conveying operation, it is necessary to determine the variation of the path helix angle 1 as a function of the radius and rotational speed of conveyor. As said above, $V_{T}$ is constant and doesn't vary with the radius. To simplify the analysis of the screw conveyor, the rotational mass and resultant forces at the effective radius $R_{e}$ is lumped as follows.

$$
R_{e}=\frac{2}{3}\left(\frac{R_{o}^{3}-R_{i}^{3}}{R_{o}^{2}-R_{i}^{2}}\right)
$$

where $R_{O}$ outside radius of screw flight.

$R_{i}$ Inner radius of radius.

The helix angle of the screw flight corresponding to $R_{e}$ is:

$$
\alpha_{e}=\tan ^{-1}\left[\left(\frac{p}{\pi D}\right)\left(\frac{R_{o}}{R_{e}}\right)\right]
$$

where $p:$ pitch.

$D=2 R_{O}=$ screw flight diameter

The helix angle $\lambda$ of the path and the speed of rotation of the shaft have relationship studied in A $\phi$ epo K. (1955), Alma K. (2005), Yoshiyuki S. and Peter AC. $(2001)^{1-3}$. With special case of the effective radius, the relationship between specific rotational speed and the helix angle is expressed as follows.

$$
\begin{gathered}
N_{S}=\frac{R_{o}}{R_{e}}\left[1+\frac{\tan \lambda_{e}}{\tan \alpha_{e}}\right]^{2} \\
{\left[\frac{k_{F} \sin \left(\alpha_{e}+\phi_{S}\right)}{\mu_{c} \cos \left(\alpha_{e}+\phi_{s}+\lambda_{e}\right)}-k_{S}\right]}
\end{gathered}
$$

where $k_{F}=\left(1-\mu_{c} k_{S}\right) \leq k_{F} \leq 1.0$ $k_{s}=2 k_{j} \frac{p}{D}\left[\frac{1}{1-\frac{R_{i}^{2}}{R_{0}^{2}}}\right] n_{F}$

$\phi_{s}$ Friction angle for screw surface;

$k_{j}: 0.4$.

$\eta_{F}$ : Fill ratio or fullness.

$\mu_{c}$ : Friction coefficient for bulk material on casing surface.

From the equation (10), the vortex efficient is shown as follows

$$
\eta_{v R}=\frac{V_{L e}}{V_{L t}}=\frac{\tan \lambda_{e}}{\tan \alpha_{e}+\tan \lambda_{e}}
$$

where $\alpha_{e}$ effective helix angle - Equation (12) $\lambda_{e}$ Effective helix angle of the path - Equation (13) 


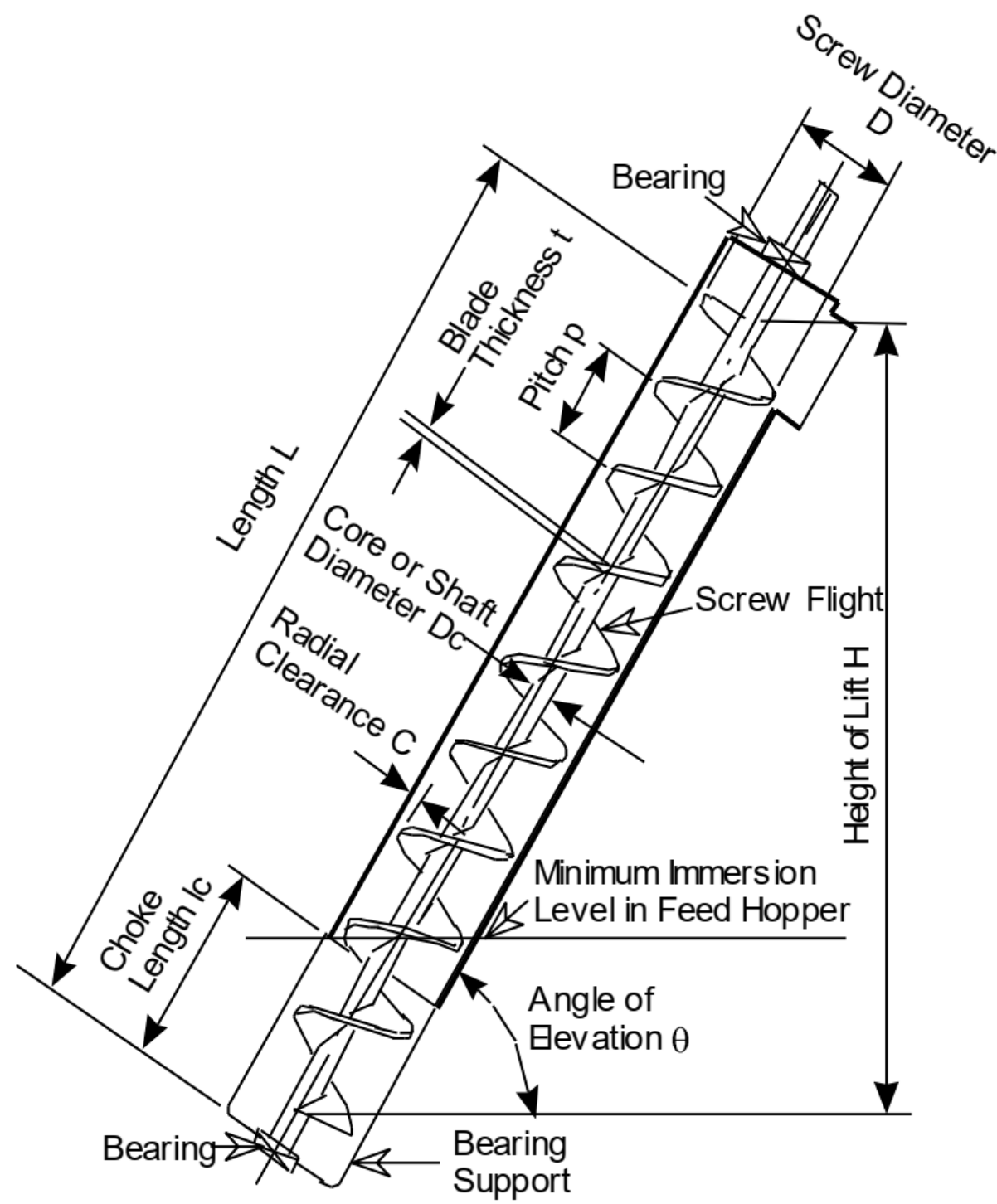

Figure 2: Structure of screw conveyor in detail

Research $^{1-4}$ showed that for horizontal screw conveyor, the angle $\beta$ (in Figure 4 ) is zero. That means the helix angle of the path is independent of the screw speed and is given by

$$
\lambda=90^{\circ}-\left(\alpha-\phi_{S}\right)
$$

This relationship may also be assumed for screw conveyors operating at low angles of elevation up to say, $\theta=25^{0}$ The conveying or vortex efficiency derived from Equation (10) and Equation (13) is expressed by

$$
\eta_{V R h}=\frac{1}{\tan \alpha_{e} \tan \left(\phi_{S}+\alpha_{e}\right)+1}
$$

The analysis for operation at any elevation angle $q$ is more complex. For inclination angles ranging from $30^{0}$ to $90^{\circ}$, Equation (13) may still applied, but in the modified form

$$
\begin{gathered}
s=\frac{R_{o}}{R_{e}}\left[1+\frac{\tan \lambda_{e}}{\tan \alpha_{e}}\right]^{2} \\
{\left[\frac{k_{F} f_{1}(\theta) \sin \left(\alpha_{e}+\phi_{s}\right)}{\mu_{c} \cos \left(\alpha_{e}+\phi_{s}+\lambda_{e}\right)}-k_{s} f_{2}(\theta)\right]}
\end{gathered}
$$

The function $f_{1}(\theta)$ and $f_{2}(\theta)$ need to be defined. When $N_{s}=f\left(\lambda_{e}\right)$ has been determined, then Equation (16) is used to determine $\eta_{V R}$ Hence the throughput may be calculated. 


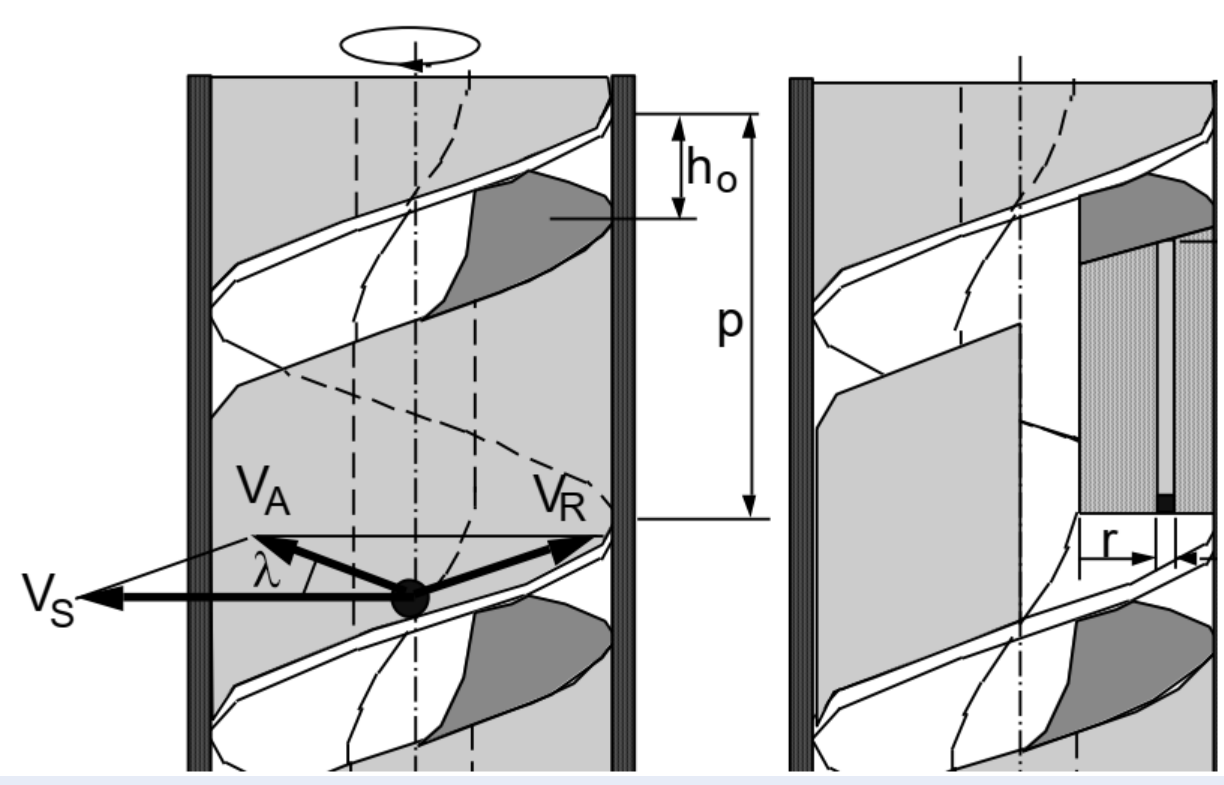

Figure 3: Dynamic of particles

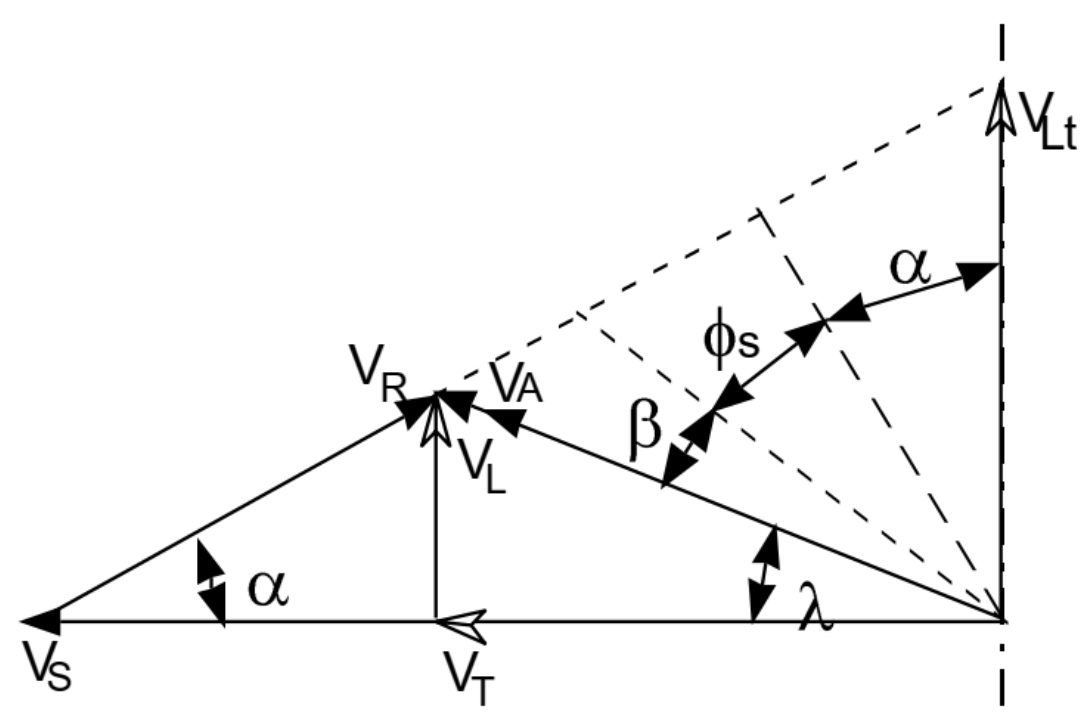

Figure 4: Unfolded velocity 
An alternative, somewhat empirical approach solution is as follows.

(a). Compute the conveying or vortex efficiency $\eta_{V R}$ for a vertical conveyor in accordance with Equations (11) and (13)

(b). Compute the conveying efficiency $\eta_{V R h}$ for a horizontal conveyor using Equation (14).

(c). Interpolate the conveying efficiency for inclination angle $q$ as follows.

$$
\eta_{V R \theta}=\eta_{V R h}-\left(\eta_{V R h}-\eta_{V R}\right) \sin \theta
$$

When the screw conveyor operates, there are two torques: the torque due to the bulk on the shaft $T_{s h}$ and torque per pitch due to the bulk solid on the flight face $T_{s p}$. The torque per pitch is determined from the following equation

$$
T_{s p}=\frac{2}{3} \frac{L}{p} \Delta F_{R A} R_{e} \tan \left(\alpha_{e}+\phi_{S}\right)
$$

where $\phi_{s}$ friction angle for bulk solid on screw surface.

$R_{e}$ Effective radius.

$\alpha_{e}$ Effective helix angle.

$L$ : length of screw conveyor.

$p:$ pitch.

The torque due to the bulk solid on the shaft is:

$$
T_{s h}=2 \pi R_{i}^{2} \sigma_{n} \frac{L}{p}
$$

where $\sigma_{n}=K \rho g p \eta_{F}$

The total torque on the shaft is:

$$
T=T_{s p}+T_{s h}
$$

Thus, the power for the motor is:

$$
P=\frac{0.105 T N}{\eta_{d}}
$$

where $\mathrm{N}$ : round per minute.

$\eta_{d}$ drive efficient.

\section{METHOD, RESULT AND DISCUSSION}

Cement is the most frequently used material in construction today. Slightly more than a ton of concrete is produced every year for each person on the planet, approximately 6 billion tons per year. It is a versatile material and can be molded to just about any shape. Cement is also strong, inexpensive, and easy to make. In this part, the cement will be experimented with screw conveyor whose parameters consist of radial clearance, angular speed and then the productivity will be measured. The cement characteristics can be shown as follows:
- Particle shape: Shape analysis will also provide information on parameters such as equivalent shape factor and aspect ratio, both of which determine the cements flow-ability. The cements particle size is now seen as critical for the determination of the quality of the cement. As finer particle size will result in a greater surface area, cement manufactures control particle size as this parameter directly affects the cement's compressive strength and curing speed. Particles larger than 50 micron cannot be fully hydrated, while particles smaller than 2 micron cause exothermal setting in the final product. In this experiment, the cement has medium size of $15.4 \mathrm{~mm}^{7}$.

- Angle of repose : The angle of repose, or critical angle of repose, of a granular material is the steepest angle of descent or dip relative to the horizontal plane to which a material can be piled without slumping. At this angle, the material on the slope face is on the verge of sliding. Following Piotr Kulinowski et al. ${ }^{8}$, cement has an angle of repose of 20 degrees.

- Hausner Ratio, A.W. Roberts (1999) ${ }^{4}$ : the Hausner ratio is derived from the quotient between tapped density (TD) and apparent density (AD). Tapped density was measured using Stamp volume meter. The Hausner ratio of cement measured is 1.27 .

- Conveying length : in this experiment, the conveying length is 3 meters.

- Flow rate: Flow rate is the time in seconds, which an amount of $50 \mathrm{~g}$ dry powder needs to pass the aperture of standardized funnel. Flow rate of cement is 35 seconds ${ }^{9}$.

- Clearance: At a large clearance a back flow of bulk material opposite to the conveying direction occurs followed by reduction in conveyor capacity. However, if clearance is small milling and jamming can take place between screw and casing. Clearance is also necessary for smooth running of the conveyor. Therefore, it is important to find the smallest clearance at which no milling and jamming process takes place.

Before make the experiment, the flow weight, moment on the shaft and the motor will be calculated and then the result will be compared with experimental data. The discussion will give remarks about the difference between theory and experiment.

Firstly, the moment on the shaft will be calculated from equation (20). This moment will help to obtain a durable shaft, to ensure to work for a long time. Then, 


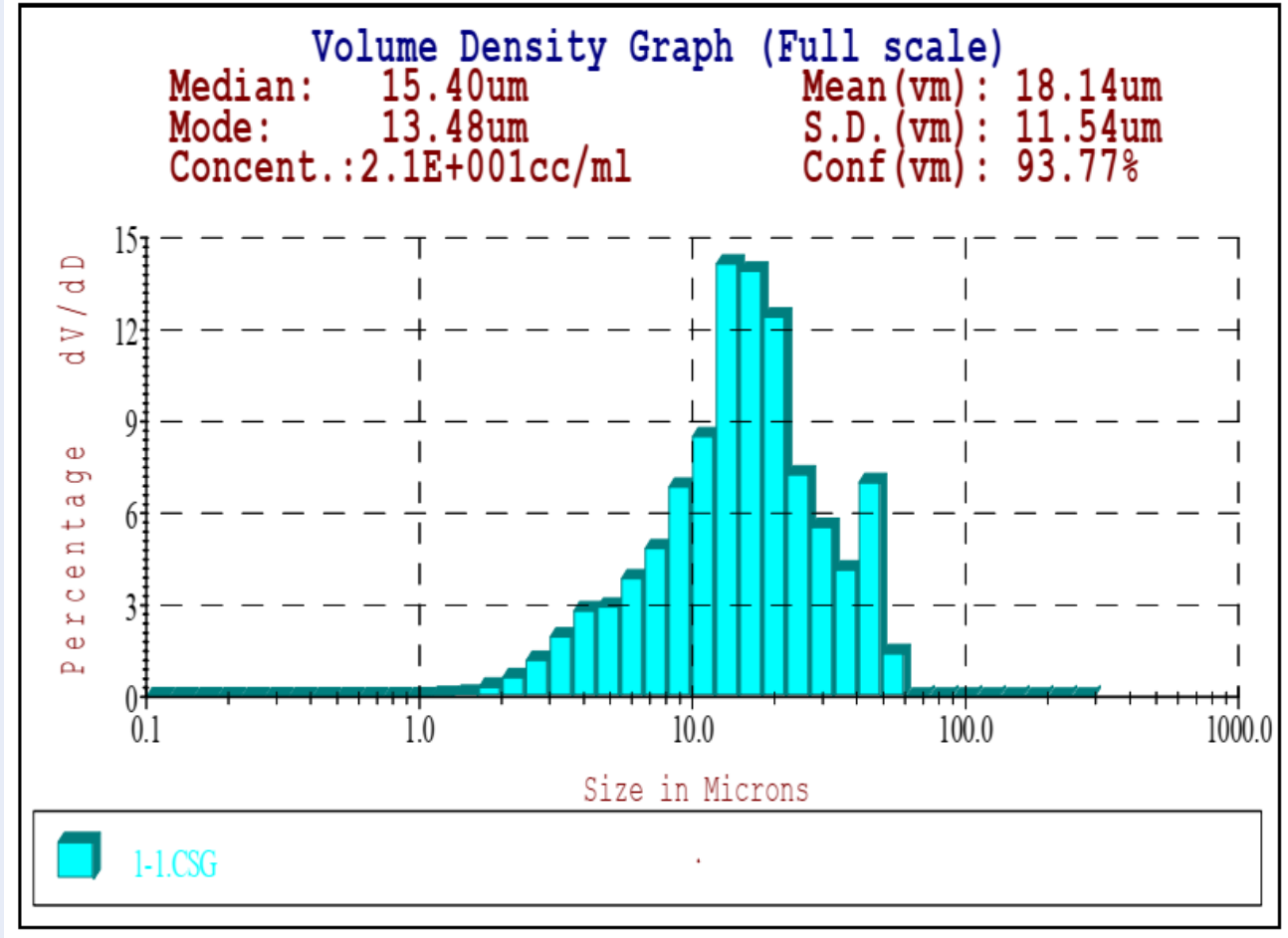

Figure 5: Particle size of particle

based on the equation (21), the power of motor will be determined. And lastly, the flow weight will be calculated from equation (8). The parameters in the formula will be directly measured from the model of conveyor. The results are shown in Figure 6. Where, the dashed line shows the angular speed of 200 round p er minute, dotted line 400 and solid line 600 . Next part, the real conveyor will be experimented and then, the result of experiment will be shown.

In the experiment, the angular speed of main shaft will be changed by a control system. The speed will be also from 100 to 700 round per minute. Three screw conveyors with different outer diameters are prepared to produce 4 different radial clearances 1, 3, 5 and 8 millimeters. The diameter of shaft and the casing are all fixed in experiment. Two parameters do not need to change because in this experiment, the effect of clearance on the productivity is being concerned.

The Figure 7 expresses the flow weight versus radial clearance. The dash line show the shaft rotates 200 round per second, the dot line is 400 and the last one is 600. Bigger t he clearance is, the more back flow it is. However, when the clearance is smaller than 3 millimeters, the jamming problem occurs and the motor will stop and then start. As a result, the medium shaft speed reduces a half. Thus, the flow weight is so low and the motor is often full load, that causes damage of the screw conveyor.

From the result of experiment and theory, some discussion can be given:

- The theory formula will not coincide with experiment result at the clearance that is smaller than $3 \mathrm{~mm}$. The reason can be explained that the theory formula doesn ' $t$ calculate the jamming between casing and screw. Thus, the productivity decrease and make the conveyor damageable.

- When the clearance is bigger than $3 \mathrm{~mm}$, the jamming phenomenon can be neglected, thus the theoretical results seem same as the real results.

- The clearance should not be so large. the productivity will decrease so fast when the clearance becomes larger.

\section{CONCLUSION}

The clearance is an important parameter to increase productivity. Following the theoretical formula, the result of productivity in the small clearance is not exact because the jamming phenomenon is not dealt with. The experiment results showed that the clearance should be 1.5 to 2 times of size of particle but 


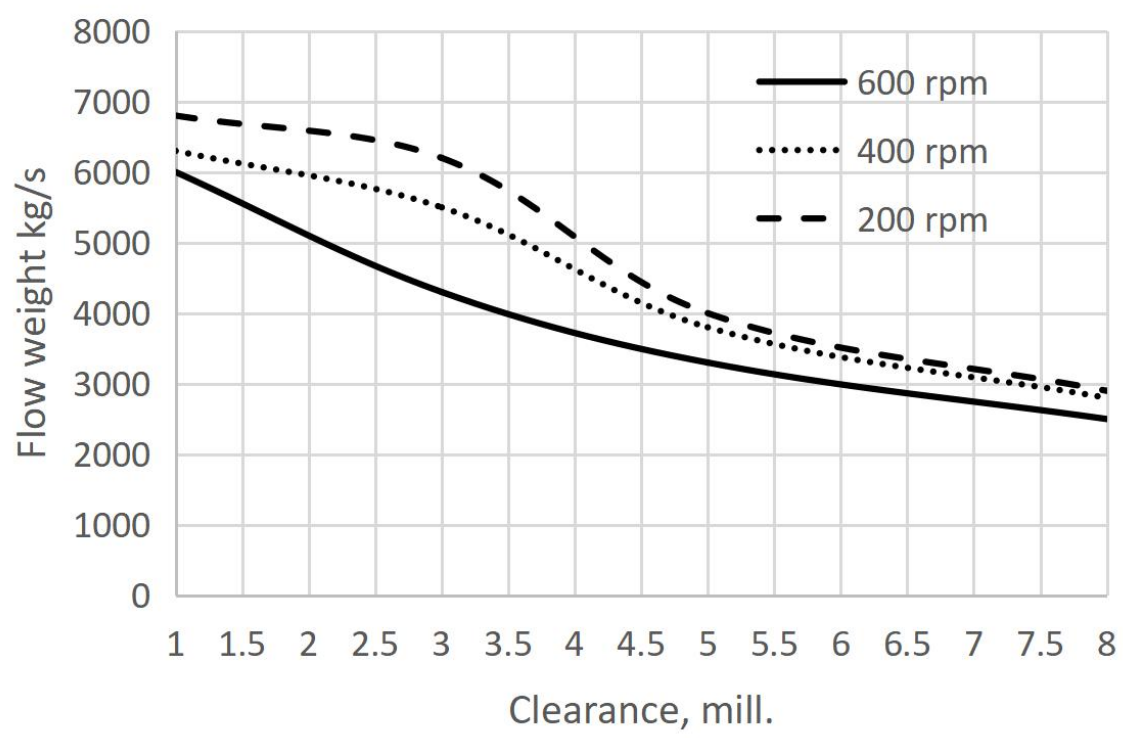

Figure 6: Flow weight with different radial clearance (Theory).

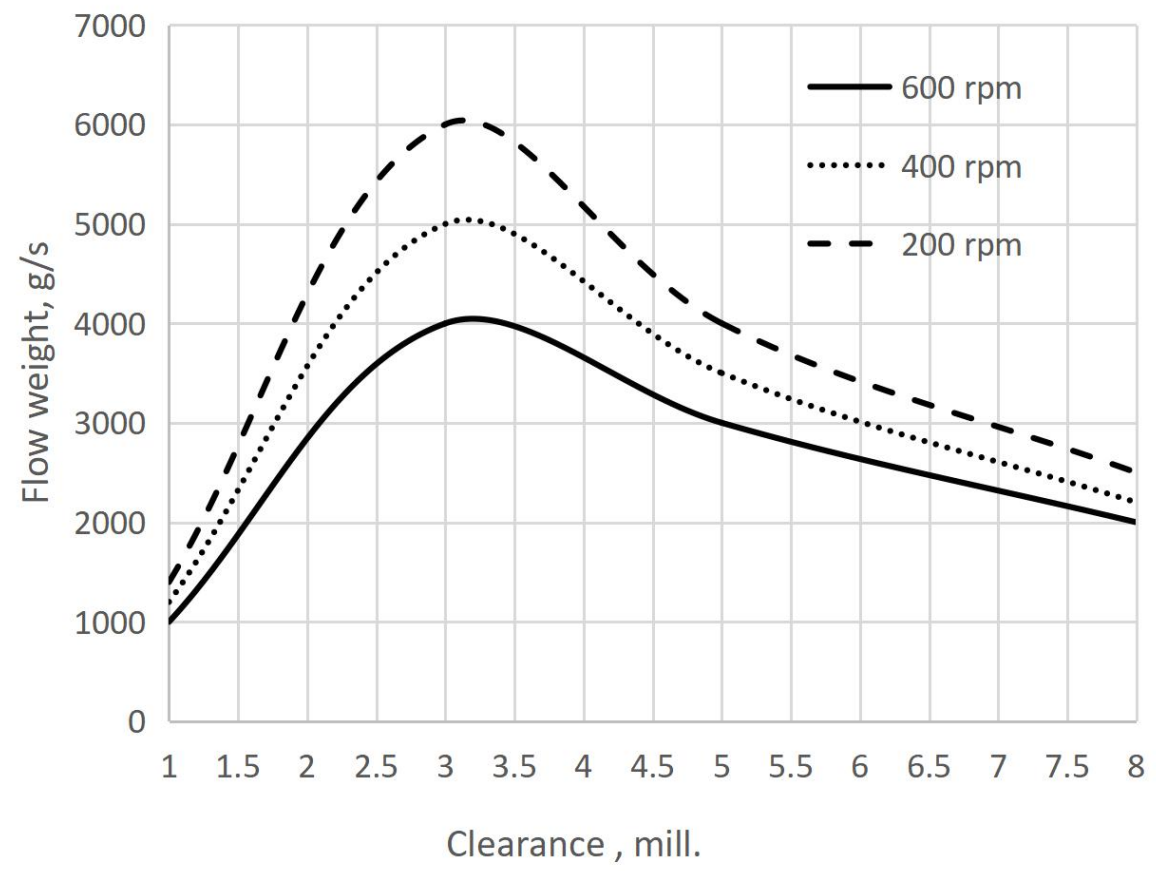

Figure 7: Flow weight with different radial clearance (Experiment). 
the minimum clearance is 3 millimeters. With cement conveying, the clearance should be 3 to 5 millimeters.

\section{ABBREVIATION}

HCMUT: Ho Chi Minh city University of Technology TD: tapped density

AD: apparent density

\section{CONFLICT OF INTEREST}

Author ensure that there is no conflict of interest in this paper.

\section{AUTHORS' CONTRIBUTION}

Tung T. Luu did works in this paper.

\section{REFERENCES}

1. Аферо К. Буере усsс Таои. Проеsс Тироаие, pacesc Ти эсуаsс Таия; 1955.
2. Kurjak A. The vertical screw conveyorpowder properties and Screw conveyor design. Lund Institute of Technology; 2005.

3. Shimizu1 Y, Cundall PA. Three-Dimensional Dem Simulations Of Bulk Handling By Screw Conveyors. Journal Of Engineering Mechanics. 2001;

4. Roberts AW. The influence of granular vortex motion on the volumetric performance of enclosed screw conveyors. Powder Technology. 1999;.

5. Philip J, Owen PW, Cleary. Screw conveyor performance: comparison of discrete element modelling with laboratory experiments. Progress in Computational Fluid Dynamics. 2010;10.

6. Owen PJ, Cleary PW. Prediction of screw conveyor performance using the Discrete Element Method (DEM). Powder Technology. 2009;.

7. Ankersmid. Particle Size and Shape Analysis of Cement Samples. APPLICATION NOTE 32. 2005;.

8. Kulinowski P, Kasza P. Properties Bulk Solids. Department of Mining, Dressing and Transport Machines;

9. Akram H, Abed AR, Abdulmunem. Investigation of combination between latent and sensible heat storage materials on the performance of flat plate solar air heater. The Iraqi Journal For Mechanical And Material Engineering. 2018;18(1):63-77. 


\section{Nghiên cứu về độ hở hướng tâm của trục vít tải để vận chuyển xi măng}

\section{Lưu Thanh Tùng*}

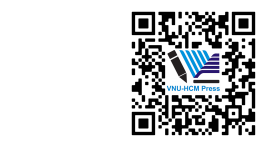

Use your smartphone to scan this QR code and download this article

\section{TÓM TẮT}

Ngày nay, trục vít tải đã được sử dụng để vận chuyển vật liệu rời qua nhiều thời đoạn lịch sử. Chúng bao gồm một cánh xoắn ốc (trục vít), trục chính được kết nối với thiết bị hướng dòng, máng chữ U hoặc ống tròn, v.v. Nguyên lý vận chuyển vật liệu phụ thuộc vào ma sát giữa vật liệu và trục vít hoăc vỏ. Uu điểm của truc vít tải là thiết kế nhỏ gon, bảo trì thấp và khả năng vân chuyển vật liêu liên tục và an toàn. Trục vít tải đã được sử dụng không chỉ là thiết bị để vận chuyển vật liệu mà còn là một bộ phận của máy móc xây dựng và khai thác, ví dụ, máy đào hầm, trong đó chúng được sư dụng để vận chuyển đất hoặc đá một cách liên tục. Là các thiết bị đo thể tích, trục vít tải thường dung để cung cấp kiểm soát khối lượng tương đối chính xác trong khi đáp ứng các yêu cầu khác, ví dụ: bảo vệ môi trường. Một bộ cấp liệu vít thường bao gồm một thùng chứa (thùng hoặc phễu) được ghép với vỏ vít và trục vít bên trong. Chúng thích hợp để vận chuyển vật liệu khô hoặc dạng hạt. Mặc dù cấu trúc cơ khí của trục vít tải có vẻ rất đơn giản, nhưng cơ chế hoạt động vận chuyển rất phức tạp. Dòng chu kỳ, độ nghiêng, tốc độ quay, độ xuyên tâm v.V ... ảnh hưởng đến năng suất, tốc độ dòng chảy. Theo các nghiên cứu lý thuyết, độ hở xuyên tâm phải rất nhỏ, tuy nhiên, trong thực tế, vật liệu không thể đi qua khe hở, làm cho trục vít bị kẹt và sau đó dừng lại. Tuy nhiên, khi độ hở bán kính lớn hơn, năng suất giảm rất nhanh. Trong bài báo này, xi măng được vận chuyển bằng trục vít tải. Thí nghiệm được thực hiện với các thông số khác nhau như tốc độ quay và độ hở xuyên tầm. Năng suất được ghi lại với mối thay đổi của các tham số. Kết quả từ thí nghiệm sể dự đoán độ hướng kính tốt nhất để vận chuyển xi măng. Bài viết sẽ kết luận khu vực có năng suất cao và năng suất thấp.

Từ khoá: Trục vít tải, tốc độ quay, sản lượng, năng suất khối lượng, khe hở hướng kính
Trường Đai học Bách khoa, ĐHQG-HCM

\section{Liên hệ}

Lưu Thanh Tùng, Trường Đại học Bách khoa, ĐHQG-HCM

Email: ttluu@hcmut.edu.vn

Lịch sử

- Ngày nhận: 01-9-2019

- Ngày chấp nhận: 22-10-2019

- Ngày đăng: 30-11-2019

DOI : 10.32508/stdjet.v2i3.577

\section{Check for updates}

\section{Bản quyền}

(c) ĐHQG Tp.HCM. Đây là bài báo công bố mở được phát hành theo các điều khoản của the Creative Commons Attribution 4.0 International license.

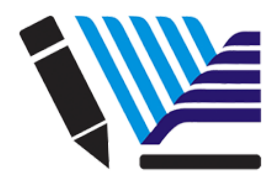

VNU-HCM Press
Trích dẫn bài báo này: Thanh Tùng L. Nghiên cứu về độ hở hướng tâm của trục vít tải để vận chuyển xi măng. Sci. Tech. Dev. J. - Eng. Tech.; 2(3):153-162. 